\title{
Species composition shift of confined bacterioplankton studied at the level of community DNA
}

\author{
SangHoon Lee*, Jed A. Fuhrman \\ Marine Biology Research Section, Department of Biological Sciences, University of Southern California, Los Angeles, \\ California 90089-0371, USA
}

\begin{abstract}
Using a new DNA hybridization technique that does not require culturing, we compared the species composition of natural planktonic bacterial assemblages before and after confinement in 201 containers for ca $2 \mathrm{~d}$. Although confinement is known to cause species shifts, possibly by stimulating growth of certain types of cells near the container wall, we found that such shifts were minor; 5 to $15 \%$ of the communities had changed during confinement. The greatest shifts occurred in the samples that had the fastest bacterial growth rate measured by $\left[{ }^{3} \mathrm{H}\right]$ thymidine incorporation. Despite the minor changes in species composition, the fraction of the cultivable cells (colony forming units; CFU) increased 4 - to 23 -fold, but amounted to $<2 \%$ of total counts even after confinement. Interestingly, CFU on unsupplemented media increased more rapidly than CFU on supplemented media. Comparisons to previous studies suggest that our use of large $(20 \mathrm{l})$ containers and our efforts to minimize contamination with organic material may have decreased the 'wall effect.' We conclude that confined microbial communities did not undergo drastic changes of species composition in $2 \mathrm{~d}$ in 201 containers.
\end{abstract}

It is well known that confinement of natural bacterioplankton assemblages affects the metabolic activities of confined organisms, and subsequently results in changes of species composition (ZoBell \& Anderson 1936, ZoBell 1943, Ferguson et al. 1984). Similar findings, e.g. major species composition shifts and population size changes, have been obtained with confined planktonic eukaryotic organisms (Venrick et al. 1977). One of the most distinctive changes during confinement of natural bacteria is the increase of colony forming units (CFU) on plate media, where nutrients are relatively enriched compared to natural seawater. The cells cultivable on those media are generally con-

\footnotetext{
- Addressee for correspondence. Present address: Oceanographic and Atmospheric Sciences Division, Brookhaven National Laboratory, Upton, New York 11973, USA
}

sidered to require high levels of nutrients in order to proliferate. A possible mechanism of species composition change under confinement is an outgrowth of high-nutrient type cells in microhabitats near the container wall, where organic materials are adsorbed from adjacent water (ZoBell 1943). This mechanism is consistent with the observation that the increase in microbial activities under confinement becomes smaller with an increase in container volume (ZoBell \& Anderson 1936, ZoBell 1943, references therein). Besides the wall effect, contained systems are considered to be different from natural systems in various ways (Ferguson et al. 1984, references therein).

Previous studies examined the confinement effect on species compositions mostly by CFU, and the change of CFU has been suggested as supportive evidence of the species shift indicative of the entire community structure change. However, most naturally occurring cells are non-cultivable (CFU $<1 \%$ of total cell counts; Ferguson et al. 1984, and this study), despite the observation that many (40 to $90 \%$ of total count) can be shown to be metabolically active by microautoradiography (Fuhrman \& Azam 1982). Use of cultivable cells alone may not be appropriate to investigate the species composition change of a whole community. The rich culture media used in the previous studies of confinement effects may have been too enriched to see the responses (or may have inhibited the activities) of cells which may require only slightly increased levels of nutrients (Baxter \& Sieburth 1984).

Lee \& Fuhrman (1990) recently presented a rapid and simple method, community DNA hybridization, for species composition comparison between bacterial communities. The method uses total DNA directly extracted from natural bacterioplankton communities, and hence does not require pure cultures. Exploiting 
the observation that total DNA does not crosshybridize significantly between species (Palleroni et al. 1973, Lee \& Fuhrman 1990), our technique measures the community DNA similarity (\%) which is an estimate of the overlapping fraction between 2 communities due to the identical or near-identical DNA species present in both samples.

The species composition similarity was presented as a summation of the minimum common fractions between 2 samples. For example, when Community A is composed of 3 species $-a, b$ and $c$-each taking up $40,30,30 \%$ of the community, respectively, and Community B with 4 species $-a, b, d$, and $e-$ each 50,20 , $20,10 \%$, then the common species are $a$ and $b$, each with the minimum common fraction of 40 and $20 \%$, respectively. The similarity is thus $40+20=60 \%$. Therefore, the similarity is an index based on the 2 parameters of the community structure, i.e. species and their frequencies. This approach was tested with mixtures of DNA from pure lab cultures, by hybridizing the DNA mixtures in a reciprocal fashion (probe and target switched) and comparing the observed similarities to the theoretical ones calculated from the known compositions of the mixtures (Lee \& Fuhrman 1990). The measured similarities approximated the expected ones under most circumstances. Although the discriminating power of DNA hybridization led to a suggestion that bacterial strains of $>70 \%$ DNA homology belong to one species (Wayne et al. 1987), strict interpretation of community DNA similarity to within a few percent is not possible, partly because there is a slight cross-hybridization between species (generally $<10 \%$ ). Details of the concept, tests and evaluations, and limitations of the method are presented in Lee \& Fuhrman (1990).

In this study, confinement effects on bacterial species compositions were examined by the community DNA hybridization method. An important difference from previous studies was the use of larger (20 1) volume containers, needed to obtain sufficient DNA for the hybridizations. We also investigated changes of $\mathrm{CFU}$, cell concentrations, and growth rates under confinement. The community DNA hybridization showed ca 5 to $15 \%$ of species composition shift while the CFU were always $<2 \%$ of the total cell count.

Materials and methods. Sampling: Naturally occurring marine planktonic bacteria were sampled (Table 1) from an oligotrophic Pacific station $(550 \mathrm{~km}$ west of San Diego, USA) at $25 \mathrm{~m}$ (OpenPac25) and $100 \mathrm{~m}$ (OpenPac100) water depths, and from a jetty at Playa Del Rey, Santa Monica Bay, Los Angeles, CA (CoastalPac). Other samples included in the community DNA comparisons were from a beach at Crane Neck, Long Island, New York, USA, (LIS) and the
Caribbean Sea (Carib; $100 \mathrm{~km}$ west of Dominica). To collect the seawater, we used Niskin bottles (OpenPac and Carib samples), or clean plastic buckets thoroughly rinsed with seawater (CoastalPac and LIS samples). The water collected with the buckets was transferred to clean (see below) 201 polyethylene containers for transport and storage (i.e. confinement).

Confinement experiment: The seawater samples were transferred to and stored in 201 polyethylene containers (Cubitainer; Consolidated Plastics Co., Inc., Twinsburg, $\mathrm{OH}, \mathrm{USA}$ ) which were soaked overnight with $10 \% \mathrm{HCl}$ and rinsed thoroughly with the sample seawater. No treatment was given except aging in 201 containers. The OpenPac25 sample was stored on the ship deck in the shade for $48 \mathrm{~h}$, and the OpenPac100 sample was stored in the ship's lab for $32 \mathrm{~h}$. The CoastalPac sample was stored indoors in the lab at University of Southern California for $48 \mathrm{~h}$. Storage temperatures were 14 to $18{ }^{\circ} \mathrm{C}$ (OpenPac) and $21^{\circ} \mathrm{C}$ (CoastalPac), whereas in situ temperatures were $17^{\circ} \mathrm{C}$ (OpenPac25), $13{ }^{\circ} \mathrm{C}$ (OpenPac100), and $20^{\circ} \mathrm{C}$ (Coastal$\mathrm{Pac})$.

Cell collection for DNA: Bacterial cells were collected by pressure filtration as described previously (Lee \& Fuhrman 1990). In brief, the water was first pre-filtered through type AE glass fiber filters (142 mm diameter; Gelman Sciences Inc., Ann Arbor, MI, USA) to remove larger particles and eukaryotic cells, and bacterial cells were collected on $0.22 \mu \mathrm{m}$ pore size Durapore filters (142 mm diameter; Millipore Corp., Bedford, MA, USA). The filtrations were done in a relatively short period of time (total of 1.5 to $3 \mathrm{~h}$ after sample collection, depending on the volume filtered). Subsamples were taken from unfiltered seawater, intermediate filtrate (between AE filter and Durapore filter) and final filtrate. Filtering efficiencies were monitored from subsamples by the acridine orange direct count (AODC) method (Hobbie et al. 1977). Filtration was done in the same way for stored seawater samples at the end of confinement.

DNA extraction: We followed the protocol of Fuhrman et al. (1988) to extract DNA from the cells collected on Durapore filters, with one more step of purification with phenol/chloroform/isoamyl alcohol ( $24: 6: 1$ by vol, $\mathrm{pH} 8.0$ ). After final purification and redissolution in TE (10 $\mathrm{mM}$ Tris, $1 \mathrm{mM}$ EDTA, $\mathrm{pH}$ 8.0) at the concentrations of 100 to $500 \mathrm{ng} \mu \mathrm{l}^{-1}$. DNA was quantified by Hoechst 33258 dye (bisbenzimide; Sigma Chemical Co., St. Louis, MO, USA) fluorometry (Paul \& Myers 1982).

Probe and target DNA preparation: Probe DNA was labeled with [alpha ${ }^{35}$ S]dATP (DuPont, NEN Research Products, Boston, MA, USA) by nick translation and purified as described previously (Lee \& Fuhrman 1990). Probes were dried by vacuum centrifugation 
Table 1. Dates and locations of natural bacterioplankton samples

\begin{tabular}{|c|c|c|c|c|}
\hline Sample & Date & Depth (m) & Location & Remarks \\
\hline OpenPac25 $5^{\mathrm{a}}$ & 25 Apr 1989 & 25 & $31^{\circ} 46^{\prime} \mathrm{N}, 124^{\circ} 05^{\prime} \mathrm{W}$ & $550 \mathrm{~km}$ west of San Diego, CA \\
\hline OpenPac100 & 21 Apr 1989 & 100 & $31^{\circ} 50^{\prime} \mathrm{N}, 124^{\circ} 07^{\prime} \mathrm{W}$ & " \\
\hline CoastalPac $^{\mathrm{b}}$ & 11 Aug 1989 & Surface $<1$ & $33^{\circ} 55^{\prime} \mathrm{N}, 118^{\circ} 30^{\prime} \mathrm{W}$ & Santa Monica Bay, Los Angeles, CA \\
\hline Carib $^{c}$ & 1 Mar 1988 & Surface $<20$ & $15^{\circ} 31^{\prime} \mathrm{N}, 62^{\circ} 21^{\prime} \mathrm{W}$ & $100 \mathrm{~km}$ west of Dominica \\
\hline LIS $^{d}$ & 18 Aug 1988 & Surface $<1$ & $40^{\circ} 58^{\prime} \mathrm{N}, \quad 73^{\circ} 09^{\prime} \mathrm{W}$ & Crane Neck, Long Is., NY \\
\hline \multirow{2}{*}{\multicolumn{3}{|c|}{$\begin{array}{l}\text { a Oligotrophic Pacific samples. Numbers } \\
\text { in name indicate sampling depth }(\mathrm{m}) \\
\text { b Coastal Pacific sample }\end{array}$}} & \multicolumn{2}{|c|}{${ }^{c}$ Caribbean Sea sample } \\
\hline & & & \multicolumn{2}{|c|}{${ }^{\mathrm{d}}$ Long Island Sound (LIS) sample } \\
\hline
\end{tabular}

(SpeedVac SVC100H, Savant Instruments Inc., Farmingdale, NY, USA), and stored frozen $\left(-20^{\circ} \mathrm{C}\right)$ until use (for $<1 \mathrm{~d}$ ). Target DNAs, which were unrestricted and unlabeled total DNA, were loaded on a nylon hybridization membrane $(0.45 \mu \mathrm{m}$ pore size, Magnagraph; Micron Separations Inc., Westborough, MA, USA) in a series of dots ( 250 and $500 \mathrm{ng}$ ), each within a $5 \times 5 \mathrm{~mm}$ square.

Hybridization and similarity calculation: General procedures and conditions for hybridizations were the same as described previously (Lee \& Fuhrman 1990), unless otherwise noted. In this study, hybridization and washing temperature was set at 68 to $69^{\circ} \mathrm{C}$. Specific radioactivity of the probes were ca 8 to $13 \times 10^{7} \mathrm{dpm}$ $\mu \mathrm{g}^{-1}$ DNA. After hybridization and washing, radioactivity of target DNA dots were counted by liquid scintillation, and similarities (\%) of samples were calculated as described in the previous study. In brief, the similarity is the percentage of sample-to-control cross-hybridization normalized to control-to-control self-hybridization.

Community DNA comparison: Community DNA at the beginning ( $t=0$, at the time of sampling) and end $(t=T)$ of confinement were compared to each other to estimate species composition changes during confinement. Community DNA at $t=0$ and $t=T$ of one sample were compared to the DNA of other samples at $t=0$ and $t=T$ to examine if any unidirectional change of the species compositions was caused by the confinement. If the confinement favored the growth of certain types of bacteria present in both of the 2 compared communities, there might be a trend that the species composition of aged Community $\mathrm{A}$ is more similar to the species composition of aged Community B than to the composition of fresh Community B. We also compared the fresh and the aged samples with the Carib and LIS samples.

CFU counting: Subsamples from 10 to $100 \mu \mathrm{l}$, depending on cell concentrations and media types, were taken at $t=0$ and $t=T$, and spread on seawater CPM plate media (enriched media; seawater filtered with glass fiber filter, $0.05 \%$ Difco Bacto-peptone, $0.05 \%$ Difco casamino acids, $1.5 \%$ Difco Bacto-agar, autoclaved; Difco Laboratories, Detroit, MI, USA), and seawater agarose media (unenriched media; seawater filtered with glass fiber filter, $1 \%$ electrophoresis grade agarose [Bethesda Research Laboratories, Gaithersburg, MD, USA], autoclaved). The seawater used for the media was from a beach near Topanga, California. The plates were incubated at room temperature (18 to $21^{\circ} \mathrm{C}$ ). $\mathrm{CFU}$ of the OpenPac plates were counted $16 \mathrm{~d}$ after the inoculation, and CFU of the CoastalPac plates were counted $8 \mathrm{~d}$ after inoculation.

Cell concentration and growth rate measurements: Cell concentrations were determined by the AODC method (Hobbie et al. 1977) from subsamples taken at $t=0$ and $t=T$. Bacterial growth rate was estimated by the [methyl $\left.-{ }^{3} \mathrm{H}\right]$ thymidine (TdR) method (Fuhrman \& Azam 1982) at $t=0$ and $t=T$, with a final concentration of $5 \mathrm{nM}$ TdR.

Results and discussion. Community DNA similarity is a measure of the fraction of identical or almost identical bacterial species present in common between 2 communities. Although the similarity index is based on species and their frequency, the similarity does not resolve individual community structure. Our laboratory tests with DNAs from pure lab cultures (Lee \& Fuhrman 1990) showed that interpretations of similarities should be on a relative scale with a major emphasis on the species contributing significant fractions. The test also revealed that asymmetric reciprocities, i.e. unidentical results from reciprocal hybridization (probe and target switched), were due primarily to the difference of community structure complexities. Hybridization of a probe DNA of a complex structure (many species) to a target DNA of a simpler structure (few species) gives a higher similarity than the reciprocal hybridization (simple probe to complex target) because of the excess of probebinding sites in the simple target. When 2 reciprocal similarities are asymmetric (for example, the OpenPac25 in Table 2), we refer to the smaller number as a best estimate, because we empirically found that the lower one of the 2 reciprocal similarities is almost always closer to the theoretical similarity. 
Table 2. Species composition similarities $(\%)$ between fresh $\left(\mathrm{at} t=0 \mathrm{~h}\right.$ ) and aged $\left(\mathrm{at} t=\mathrm{T}^{\mathrm{a}} \mathrm{h}\right)$ samples determined by community DNA hybridization. Italicised similarities indicate species composition changes after confinement. See Table 1 for sample names

\begin{tabular}{|c|c|c|c|c|c|c|}
\hline \multirow[t]{3}{*}{ Target } & \multicolumn{6}{|c|}{ Probe } \\
\hline & \multicolumn{2}{|c|}{ OpenPac25 } & \multicolumn{2}{|c|}{ OpenPac100 } & \multicolumn{2}{|c|}{ CoastalPac } \\
\hline & $t=0^{\mathrm{a}}$ & $t=T^{\mathrm{a}}$ & $t=0$ & $t=T$ & $t=0$ & $t=T$ \\
\hline OpenPac25 $t=0$ & $-^{\mathrm{b}}$ & $95(10)^{\mathrm{c}}$ & $33(2)$ & $35(3)$ & $22(4)$ & $21(2)$ \\
\hline OpenPac $25_{t=48}$ & $124(9)$ & - & $28(2)$ & $36(<1)$ & $27(4)$ & $26(1)$ \\
\hline OpenPac $100_{t=0}$ & $\mathrm{ND}^{d}$ & ND & - & $92(5)$ & $24(4)$ & $21(3)$ \\
\hline OpenPac $100_{t=32}$ & ND & ND & $94(5)$ & - & $25(3)$ & $23(1)$ \\
\hline CoastalPac $_{t=0}$ & ND & ND & ND & ND & - & $91(1)$ \\
\hline CoastalPac $_{t=48}$ & ND & ND & ND & ND & $84(2)$ & - \\
\hline Carib & $21(2)$ & $13(2)$ & $16(1)$ & $19(<1)$ & $7(2)$ & $8(1)$ \\
\hline LIS & $7(2)$ & $1(<1)$ & $7(1)$ & $8(<1)$ & $22(<1)$ & $20(1)$ \\
\hline \multicolumn{7}{|c|}{$\begin{array}{l}{ }^{\mathrm{a}} \text { Fresh samples at } t=0 \text { and aged (in container) samples at } t=T \text {. } \\
T(\mathrm{~h}) \text { values of samples are shown in first column (Target) }\end{array}$} \\
\hline \multicolumn{3}{|c|}{${ }^{\text {b}}$ Self-hybridization, defined as $100 \%$ similarity } & ${ }^{\mathrm{d}}$ Not & ined & & \\
\hline
\end{tabular}

Community DNA similarities between fresh and confined samples were 84 to $95 \%$, indicating that 5 to $16 \%$ of the species compositions had shifted during 32 to $48 \mathrm{~h}$ of confinement (Table 2). The OpenPac25 community changed $5 \%$ (95\% similar) and the OpenPac100 community changed $8 \%$ (92\% similar). The CoastalPac community changed most (16\%), being $84 \%$ similar between the fresh community and the aged one. However, only the CoastalPac sample changed its species composition significantly $(\mathrm{p}<0.05$, $t$-test) from $100 \%$. There may indeed have been real changes in the other samples, but showing statistical significance would require more replicates.

The species composition changes were reflected in growth rates of samples (Table 3); OpenPac25 grew most slowly and community DNA changed $5 \%$; OpenPac100 was intermediate (8\% change); and CoastalPac grew most rapidly (16\% change). Since measured growth rate is the rate averaged over the whole community, it is unknown how rapidly individual population sizes changed in a community. However, this indicates in general that a fast-growing community has the ability to change its species composition rapidly, as one might expect. The species composition changes were more closely related to growth rate than to the other parameters measured in this study.

Cross-hybridizations of one set of fresh and aged samples to another set of fresh and aged samples (Table 2), for instance, CoastalPac at $t=0$ and $t=T$ to OpenPac25 at $t=0$ and $t=T$, did not show any significant unidirectional change of species compositions. There was no clear trend for the species composition of fresh Community $\mathrm{A}$ to be more similar to the species composition of fresh Community B than to the composition of aged Community B. The trend was marginal (e.g. OpenPac100 $t=0$ was closer to OpenPac25 $t=0$ [33\%] than to OpenPac25 $t=T$ [28\%]), or reversed (see Table 2). This needs further investigation.

Cell concentrations showed a general decrease of ca $10 \%$ on the average during confinement, however OpenPac 25 was the only one that changed significantly $(\mathrm{p}<0.05$, ANOVA). Growth rates decreased $(\mathrm{p}<0.05$,

Table 3. Cell concentrations (by AODC) and growth rates (by [methyl $\left.{ }^{3} \mathrm{H}\right]$ thymidine incorporation) before $(t=0)$ and after $(t=T)$ the confinement. See Table 1 for sample names

\begin{tabular}{|c|c|c|c|}
\hline Sample & $\begin{array}{l}\text { Cell conc. }^{a} \\
\left(\times 10^{5} \mathrm{ml}^{-1}\right)\end{array}$ & $\begin{array}{l}\text { TdR uptake per cell } \\
\left(\times 10^{-20} \mathrm{~mol} \mathrm{cell}^{-1} \mathrm{~d}^{-1}\right)\end{array}$ & $\begin{array}{l}\text { Estimated growth rate } \\
\qquad\left(\mathrm{d}^{-1}\right)\end{array}$ \\
\hline OpenPac $25_{t=0}$ & $7.6(0.4)$ & $1.6(0.1)$ & 0.06 \\
\hline OpenPac25 $t=48$ & $6.6(0.2)$ & $1.6(0.3)$ & 0.06 \\
\hline OpenPac100 $t=0$ & $8.8(0.4)$ & $2.4(<0.1)$ & 0.10 \\
\hline OpenPac100 $t=32$ & $8.0(0.5)$ & $1.8(0.2)$ & 0.07 \\
\hline CoastalPac $_{t=0}$ & $31.7(1.3)$ & $21.3(0.1)$ & 0.43 \\
\hline CoastalPac $_{t=48}$ & $29.1(1.4)$ & $18.7(0.6)$ & 0.38 \\
\hline
\end{tabular}


ANOVA) by ca $20 \%$ on the average, except OpenPac25. The decreases were generally minor and some are not significant, but they were opposite to previous observations (ZoBell 1943, Ferguson et al. 1984, references therein).

However, it is noteworthy that the unfiltered treatment of Ferguson et al. (1984), which is comparable to the sample treatment of our study (in effect, no treatment), showed almost no increase of AODC except for 1 case (2- to 3 -fold increase during $32 \mathrm{~h}$ of confinement). Since the decrease occurred in most of the cases and was comparable each time, this probably was a consequence of the confinement. The large volume $(201)$ of the container we used should have lowered the wall effect in theory by decreasing the surface-to-volume ratio (ZoBell \& Anderson 1936, ZoBell 1943), compared with the previous studies where the container sizes were 31 (Ferguson et al. 1984) or <1 1 (ZoBell 1943).

In a similar study of confined microplankton (phytoand microzoo-plankton) in $250 \mathrm{ml}$ containers, Venrick et al. (1977) observed that nearly all components of the confined systems decreased in abundance after $24 \mathrm{~h}$ of confinement. Considering that the samples of Venrick et al. (1977) were from relatively oligotrophic open ocean seawater, it is possible that the initial nutrient level of sample water affects the confinement effects to some extent. Extreme care should be taken to avoid inadvertent contamination of a seawater sample during handling.

The highest number and percent of CFU on CPM medium were found in the CoastalPac sample; CFU and \% CFU were more than 10 times those from other samples (Table 4). This may suggest that cells favoring a high nutrient concentration are more abundant in coastal waters, where nutrient levels are usually higher and suspended organic particles are more abundant than in the open ocean. A similar trend, i.e. a gradient of CFU and \% CFU between coastal and oceanic environments, was observed by Kogure et al.
(1980). They also reported that CFU increase with increase of particulate organic material in seawater. Our culture media, which were inevitably contaminated with trace metals from the added substance and autoclave procedure, may have affected metal-sensitive cells that are likely more abundant in oceanic environments (Ferguson \& Sunda 1984). In our study, cells cultivable on agarose medium were very rare $(<0.1 \%$ of total cell count) and relatively equally abundant, unlike the cells cultivable on CPM medium, in the 3 seawater samples (Table 4).

Cells cultivable on relatively unenriched media (seawater agarose) increased 4 to 23 times in 32 to $48 \mathrm{~h}$, while cells cultivable on enriched media (seawater CPM) increased only 3 to 7 times in the same period (Table 4). The increases were significant $(\mathrm{p}<0.05$, ANOVA) except for the agarose CFU of the OpenPac samples $(\mathrm{p}<0.1)$. Previous studies reported a significantly higher rate of CFU increase, for instance, more than 2 orders of magnitude in 30 to $34 \mathrm{~h}$ (Ferguson et al. 1984), even though initial \% CFU values were comparable to those of our study. This difference is possibly due to the larger container volume $(201)$ used by us, compared to Ferguson et al. $(1984 ; 31)$. Alternatively, the difference may be due to the difference of bacterioplankton species compositions between the 2 studies. As we reported previously (Lee \& Fuhrman 1990, 1991), and discussed below, seawater from different locations is very likely to contain different types of cells.

Previous studies used heavily enriched media to isolate and count CFU (Buck 1974, Ferguson 1984). In our study, we used relatively unenriched medium (agarose) and moderately enriched medium (CPM). Natural nutrient levels must be closer to those of the seawater agarose medium than to those in CPM or other types of media previously used. From the observation that the CFU on the unenriched agarose media increased more rapidly than the CFU on the enriched CPM media, we hypothesize that cells able to

Table 4. CFU on enriched media $\left(\mathrm{CPM}^{\mathrm{a}}\right)$ and relatively unenriched media (Agarose $\left.{ }^{\mathrm{b}}\right)$ before $(t=0)$ and after confinement. Data from triplicates and SEM in parentheses. See Table 1 for sample names

\begin{tabular}{|c|c|c|c|c|}
\hline \multirow[t]{2}{*}{ Sample } & \multicolumn{2}{|c|}{$\mathrm{CPM}^{\mathrm{a}}$} & \multicolumn{2}{|c|}{ Agarose $^{\mathrm{b}}$} \\
\hline & $\mathrm{CFU} \mathrm{ml} \mathrm{m}^{-1}$ & $\% \mathrm{CFU}^{\mathrm{c}}$ & $\mathrm{CFU} \mathrm{ml} \mathrm{ml}^{-1}$ & $\% \mathrm{CFU}$ \\
\hline OpenPac25 $t=0$ & $216(20)$ & 0.028 & 43 (28) & 0.006 \\
\hline OpenPac $25_{t=48}$ & $673(78)$ & 0.102 & $179(61)$ & 0.027 \\
\hline OpenPac100 $t=0$ & $100(33)$ & 0.011 & $15(10)$ & 0.002 \\
\hline OpenPac100 $t=32$ & $661(140)$ & 0.083 & 395 (217) & 0.049 \\
\hline CoastalPac $_{t=0}$ & $10733(1029)$ & 0.34 & $119(26)$ & 0.004 \\
\hline CoastalPac $_{t=48}$ & 46100 & 1.58 & $2741(222)$ & 0.094 \\
\hline
\end{tabular}


utilize a small nutrient enrichment may play a major role in the species composition change caused by the confinement.

Regarding our method of bacterial cell collection, filtration efficiency tests showed that pre-filtration by the glass fiber AE filters removed about 7 to $9 \%$ of the total bacterial cells; ca $<1 \%$ passed through the Durapore filters. Although no thorough examination was performed, small eukaryotes were rarely found in the AE glass fiber filtrates. We did not find any systematic difference of filtration efficiencies between the samples at $t=0$ and $t=T$, however Ferguson et al. (1984) observed that the size frequency distribution shifted to larger sizes after confinement. The prefiltration removed a slightly higher percentage $(9 \%)$ of cells from the CoastalPac sample, and this is probably due to larger cells or the higher abundance of cells attached to particles in coastal waters. For instance, particle-associated bacterial cells in the CoastalPac sample ranged from $2 \%(t=0)$ to $3 \%(t=T)$ of total counts. Our data (AODC, CFU, growth rate) other than the community DNA hybridization were obtained with no particular cells excluded. Cells removed by AE prefiltration, and thus excluded from community DNA comparisons, may show different responses under confinement. However, ca $90 \%$ of the communities ( 7 to $9 \%$ removed by pre-filtration) already showed 5 to $15 \%$ changes of the species compositions by community DNA hybridization.

Recently it has been shown that viruses are abundant and infect a significant portion of the bacterial population (Proctor \& Fuhrman 1990). This raises the question of how viruses affect the results reported here. First, our use of $0.22 \mu \mathrm{m}$ Durapore filters allows most of the free viruses to pass; even those that are caught contain only about $0.08 \mathrm{fg}$ DNA per virus (Bratbak et al. 1990), that is only $10^{-1}$ to $10^{-2}$ of bacterial cellular DNA content (Lee \& Fuhrman 1991, references therein). However, the viral DNA within infected bacteria (including lysogens) was included in our measurements, because it was probably coextracted with host DNA. From literature data (Bratbak et al. 1990, Proctor \& Fuhrman 1990, 1991), we estimate that $<10 \%$ of the microbial DNA in our samples is viral. For the purposes of this study, we consider the viruses within infected bacteria to be part of the microbial community, so they were included in the comparisons.

Although the particle-associated populations were minor ( $\leq 3 \%$ of total count) and consistently excluded from the community DNA hybridization, there are some potentially important considerations; for example, it is poorly understood whether attached bacteria switch their living mode freely to planktonic freeliving, or what percentage of the attached bacteria are cultivable, etc. It is also unclear whether the CFU increase is due solely to cell division within the cultivable cell population, or a physiological shift to cultivable state of those cells that were non-cultivable prior to the confinement. The \% CFU can also be greatly affected by plating efficiency. With current knowledge, we could not assess the significance of those considerations. Poindexter (1981) and Roszak \& Colwell (1987) discussed some aspects of the above questions. Further investigations on the control mechanisms at the level of gene expression may help resolve those questions.

Regardless of confinement, species compositions of the oligotrophic Pacific samples from 2 different depths (25 and $100 \mathrm{~m}$ ) were consistently different from each other, being only ca $35 \%$ similar (Table 2 ). The 2 oligotrophic Pacific samples were different from the samples of coastal Pacific (ca $25 \%$ similar), Caribbean Sea (ca $15 \%$ ), and Long Island Sound (ca $5 \%$ ). These data imply that the samples from the open and the coastal Pacific shared some common species $(25 \%)$, although they are ca $500 \mathrm{~km}$ apart. Interestingly, the 2 oligotrophic Pacific samples were closer to the Caribbean sample (ca $15 \%$ ) than to the LIS sample (ca $5 \%$ ), and the coastal Pacific sample was closer to the LIS sample $(20 \%)$ than to the Caribbean sample $(8 \%)$. This suggests that the coastal environments of the Atlantic and the Pacific share some common species, as do the oligotrophic environments. Spatial and temporal variations of bacterioplankton species compositions are presented and discussed with more data by Lee \& Fuhrman (1991).

The community DNA hybridization showed that bacterioplankton underwent a modest shift in species compositions during confinement. Previously, the confinement effect on species compositions has been studied by mainly focusing on the change of CFU on enriched media. We conclude that community DNA hybridization, independent of the CFU count, was very useful for the investigation of the species composition change.

Acknowledgements. We thank J. Poindexter and D. Dykhuizen for critical review of the manuscript, G. Lopez, D. Lonsdale, and P. Kemp for helpful discussions, and Matt Petre for help with lab procedures. Comments from anonymous reviewers are valued. E. Carpenter and D. Capone offered the shiptime for the Caribbean cruise. We thank the ship personnel of RV 'New Horizon' and 'Columbus Iselin'. This work was supported by National Science Foundation grants OCE8716998 and OCE-8996117.

\section{LITERATURE CITED}

Baxter, M., Sieburth, J. McN. (1984). Metabolic and ultrastructural response to glucose of two eurytrophic bacteria 
isolated from seawater at different enriching concentrations. Appl. environ. Microbiol. 47: 31-38

Bratbak, G., Heldal, M., Norland, S., Thingstad, T. F. (1990). Viruses as partners in spring bloom microbial trophodynamics. Appl. environ. Microbiol. 56: 1400-1405

Buck, J. D. (1974). Effects of medium composition on the recovery of bacteria from sea water. J. exp. mar. Biol. Ecol. 15: $25-34$

Ducklow, H. W., Hill, S. M. (1985). Tritiated thymidine incorporation and the growth of heterotrophic bacteria in warm core rings. Limnol. Oceanogr. 30: 260-272

Ferguson, R. L., Buckley, E. N., Palumo, A. V. (1984). Response of marine bacterioplankton to differential filtration and confinement. Appl. environ. Microbiol. 47: 49-55

Ferguson, R. L., Sunda, W. G. (1984). Utilization of amino acids by planktonic marine bacteria: importance of clean technique and low substrate additions. Limnol. Oceanogr. 29: $258-274$

Fuhrman, J. A., Azam, F. (1982). Thymidine incorporation as a measure of heterotrophic bacterioplankton production in marine surface waters: evaluation and field results. Mar. Biol. 66: 109-120

Fuhrman, J. A., Comeau, D. E., Hagström, A., Chan, A. M. (1988). Extraction from natural planktonic microorganisms of DNA suitable for molecular biological studies. Appl. environ. Microbiol. 54: 1426-1429

Hobbie, J. E., Daley, R. R., Jasper, S. (1977). Use of Nuclepore filters for counting bacteria by fluorescence microscopy. Appl. environ. Microbiol. 33: 1225-1228

Kogure, K., Simidu, U., Taga, N. (1980). Distribution of viable marine bacteria in neritic seawater around Japan. Can. J, Microbiol. 26: 318-323

Lee, S., Fuhrman, J. A. (1990). DNA hybridization to compare species compositions of natural bacterioplankton assemblages. Appl. environ. Microbiol. 56: 739-746

This note was presented by N. Fisher, Stony Brook, New York, USA
Lee, S., Fuhrman, J. A. (1991). Spatial and temporal variation of natural bacterioplankton assemblages studied by total genomic DNA cross-hybridization. Limnol. Oceanogr. 36: $1277-1287$

Palleroni, N. J., Kunisawa, R., Contopoulou, R., Doudoroff, M. (1973). Nucleic acid homologies in the genus Pseudomonas. Int. J. syst. Bacteriol. 23: 333-339

Paul, J. H., Myers, B. (1982). Fluorometric determination of DNA in aquatic microorganisms by use of Hoechst 33258. Appl. environ. Microbiol. 43: 1393-1399

Poindexter, J. S. (1981). The caulobacters: ubiquitous unusual bacteria. Microbiol. Rev. 45: 123-179

Proctor, L. M., Fuhrman, J. A. (1990). Viral mortality of marine bacteria and cyanobacteria. Nature, Lond. 343: 60-62

Proctor, L. M., Fuhrman, J. A. (1991). Roles of viral infection in organic particle flux. Mar. Ecol. Prog. Ser. 69: 133-142

Roszak, D. B., Colwell, R. R. (1987). Survival strategies of bacteria in the natural environment. Microbiol. Rev. 51 365-379

Venrick, E. L., Beers, J. R., Heinbokel, J. F. (1977). Possible consequences of containing microplankton for physiological rate measurements. J, exp. mar. Biol. Ecol. 26: 55-76

Wayne, L. G., Brenner, D. J., Colwell, R. R., Grimont, P. A. D. Kandler, O., Krichevsky, M. I., Moore, L. H., Moore, W. E. C., Murray, R. G. E., Stackebrandt, E., Starr, M. P., Trüper, H. G. (1987). Report of the ad hoc committee on reconciliation of approaches to bacterial systematics. Int. J. syst. Bacteriol. 37: 463-464

ZoBell, C. E. (1943). The effect of solid surfaces upon bacterial activity. J. Bacteriol. 46: 39-56

ZoBell, C. E., Anderson, D. Q. (1936). Observations on the multiplication of bacteria in different volumes of stored sea water and the influence of oxygen tension and solid surfaces. Biol. Bull. mar. biol. Lab., Woods Hole 71: $324-342$

Manuscript first received: June 28, 1990

Revised version accepted: November 14, 1991 